\title{
СОЦІОКУЛЬТУРНИЙ АСПЕКТ КОМУНІКАТИВНИХ ТАБУ
}

Єловська Ю. В. Соціокультурний аспект комунікативних табу.

У статті на матеріалі мовлення українців розглядається взаємозв'язок комунікативних табу з іншими видами культурних заборон, визначаються характерні ознаки цих явищ, а також виокремлюються специфічні особливості, притаманні комунікативним табу в процесі спілкування.

Ключові слова: спілкування, комунікація, комунікативне табу, культурне табу.

๑ Ю. В. Єловська, 2013.

$-173-$ 
Еловская Ю. В. Социокультурный аспект коммуникативных табу.

В статье на материале речи украинцев рассматривается взаимосвязь коммуникативных табу с другими видами культурных запретов, выделяются характерные признаки этих явлений, а также определяются специфические черты, свойственные коммуникативным табу в процессе общения.

Ключевые слова: общение, коммуникация, коммуникативное табу, культурное табу.

Yelovska Yuliya. Sociocultural aspects of communicative taboos

This article investigates communicative taboo interrelation with other cultural bans. It defines their specific features and identifies communicative taboo peculiar signs on the Ukrainians' speech basis.

Key words: speech, communication, communicative taboo, cultural taboo.

Розвиток лінгвістичної науки XX-XXI ст., на думку багатьох учених (Н. Формановська, В. Ригованова, О. Осиянова, Н. Заніздра та ін.), характеризується прагненням дослідників до поєднання лінгвістики 3 іншими суміжними галузями гуманітарних знань, зокрема психологією, соціологією, культурологією, філософією. Цей процес супроводжується появою нових інтегрованих напрямів сучасного мовознавства, а саме: когнітивної лінгвістики, психолінгвістики, соціолінгвістики, комунікативної лінгвістики, лінгвокультурології тощо. Інтереси сучасних науковців викликають здебільшого не особливості структури й побудови мови, а іiі безпосереднє функціонування й застосування.

Головні питання, які хвилюють сучасних дослідників-лінгвістів, - це використання людиною мови як засобу спілкування та іiї власне відображення в тих мовних одиницях, які вона використовує [7, с. 346, 10, с. 4]. Погодимося з О. Осиянвою, що важливим у лінгвістичних розвідках останніх десятиліть $\epsilon$ вивчення залежності успішного спілкування від можливостей комунікантів впливати один на одного та вживати такі мовні одиниці, які адекватно відповідають комунікативній ситуації.

Услід за Н. Заніздра зазначимо, що особливе зацікавлення викликають перешкоди ефективності спілкування, комунікативні збої, надто велика метафоричність, неточність вираження думки, паузи, алогізми, непослідовність, незнання мовної компетентності адресата, розбіжності обсягу внутрішнього словника комунікантів, їхніх концептуальних систем, стратегій, мовленнєвої тактики, поведінки, різні психічні особливості, зовнішні перешкоди тощо [2, с. 24]. Зважаючи на перелічені бар'єри, що спричиняють виникнення непорозумінь між мовцем i реципієнтом у комунікативному акті, вважаємо доцільним акцентувати увагу й на визначенні впливу системи комунікативних табу на процес спілкування.

Феномен табу є предметом дослідження багатьох галузей наукового знання. Його специфіку вивчають у культурологічному, соціологічному, психологічному й інших аспектах. Тлумачення цього поняття зустрічаємо 
в наукових працях таких учених, як 3. Фрейд, Дж. Фрезер, Е. Тейлор, Ф. Бацевич, Л. Фроляк, Н. Мечковська, І. Стернін, А. Кацев, В. Кашкін, Р. Газізов, Я. Попова та інші.

Зважаючи на специфічний різноплановий характер табу, розглянемо його в площині процесу комунікації, на основі аналізу мовлення українців, виявимо соціокультурну детермінованість комунікативних табу, а також виокремимо специфічні ознаки, властиві цьому явищу. Означене є метою цієї розвідки.

Л. Гришаєва тлумачить табу як культурний феномен, який сприяв перетворенню людини з біологічної істоти в соціальну. Учена пояснює табу як соціальний зразок взаємодії між інтерактантами в тих чи тих умовах [1, с. 287]. Погодимося з Л. Цуриковою, яка співвідносить явище табу зі сферою конвенціональних заборон на певні форми поведінки, зокрема комунікативної. Дослідниця наголошує, що ці заборони завжди культурно зумовлені, часто не вмотивовані й довільні. Науковець вважає, що табу - це суворі жорсткі й абсолютні заборони для всіх членів соціуму й культурної спільноти загалом [1, с. 289].

Беззаперечним $є$ i той факт, що явище табу охоплює комунікативну сферу життя людини. Оскільки цей феномен залишається культурно й соціально детермінованим явищем, можемо припустити, що риси, властиві табу як культурному явищу, релевантні й у процесі спілкування. Розглянемо явища культурних, зокрема комунікативних табу, й зробимо спробу виокремити їхні риси.

Л. Гришаєва зазначає, що зміст культурних табу відомий кожному члену соціуму; такої думки дотримується й професор Л. Цурикова. Загальне усвідомлення, а отже й слідування цим приписам формує сприйняття подібних заборон усіма членами суспільства, i тим самим розкриває загальнокультурний характер цього феномена. Схожі риси знаходимо в комунікативних табу.

Нагадаємо, що табу в процесі спілкування пов'язують із заборонами на вживання певних слів, словосполучень і тем. Сучасні лінгвістичні розвідки Я. Попової, Р. Газізова, Ф. Бацевича підтверджують, що цей феномен має більш розгалужену систему обмежень. Забороненими, на думку вчених, є особливості тону, інтонації, певний спектр звуків, різноманітні письмові знаки. Крім того, Ф. Бацевич виділяє коло осібкомунікантів, яких не бажано згадувати, надто з ними спілкуватися.

Зважаючи на загальнокультурний характер табу як соціокультурного феномена, припустимо наявність такої властивості й у комунікативних табу, чому знаходимо підтвердження в лінгвістичних розвідках багатьох учених. Так, професор Юнг Чен Ву у своїй роботі «Табу і викладання англійської мови - міжкультурна перспектива» окреслює ознаки табу i вважає, що загальнокультурний характер табу виражається у слідуванні () Ю. В. Єловська, 2013. 
приписам i заборонам, які функціонують у суспільстві, всіма його членами незалежно від їхньої культурної належності [11]. Такої ж думки дотримується й Ман-Пінг Чу, зазначаючи, що в будь-якій мовній системі існують певні слова, словосполучення, яких намагаються уникати всі носії цієї мови через різні екстралінгвістичні чинники (етика, мораль, цензура, страх тощо) [12, с. 124].

На загальнокультурний i універсальний характер табу як його специфічну ознаку також указують у своїх наукових розвідках А. Кацев і Я. Попова. На думку вчених, усі представники соціуму повинні дотримуватися певних табу в мовленні. Хоч А. Кацев зазначає, що сувора заборона поширюється не лише на брутальні й грубі вирази й теми, а й також на ті, які пов'язані з людськими фізіологічними особливостями або актами. Із міркувань цензури їх доцільно вилучати 3 літературного мовлення, уникати за присутності жінок, у формальному й офіційноділовому спілкуванні [4, с. 34].

Загальноприйнятим правилом, яким керуються мовці в українському суспільстві, є неприпустимість вживання лайливих і брутальних слів у повсякденному спілкуванні. Основна причина заборон - етичні й моральні міркування. Нечемним у розмові вважається й відкрите інформування про певні фізіологічні потреби людини. Небажаними в комунікації виступають також теми, які пов'язані 3 обговорюванням хвороб чи смерті. Так, наприклад, в українській мові збереглися позначення деяких хвороб не тільки в їхніх прямих назвах, наприклад, лихоманка, вicna, холера, а й у ряді лексем-замінників, які, за народним повір'ям, при вживанні в мовленні були своєрідними мовленнєвими оберегами. Д. Зеленін групує ці назви за такими категоріями: ласкаві звертання й назви, що виражають повагу (кума, тітка, панна); назви-натяки (та, кого не називають; вона); назви образливого характеру (поганка, лиха, худа). Такі слова-замінники говорять про бажання комунікантів утриматися від прямого називання хвороб, а виникнення цих евфемістичних лексем пов'язане 3 побоюваннями накликати хворобу на себе, промовляючи їі імення. 3 тих самих причин у спілкуванні намагаються уникати й прямого вживання слова смерть. Д. Зеленін зазначає, що іменників, які б називали цю подію, досить мало, й навпаки, їі більше характеризують дієслова пропасти, піти, спочити, заснути, покласти на лави тощо [3, с. 64-65, 77, 152-155].

Уважаємо доцільним підкреслити, що загальнокультурний характер табу слід убачати не лише в колективному дотриманні заборон, а й в універсальній наявності цього явища в будь-якій мовній системі. МанПінг Чу наголошує, що певні обмеження, пов'язані 3 окремими аспектами життя, притаманні як західним, так і східним культурам. На нашу думку, ці заборони необов'язково мають бути тотожні, але їхнє існування й вербалізація є безперечним фактом. 
Погодимося з К. Шилихіною, що явище табу безумовно пов'язане 3 особливостями культури, 3 тим, що видається представникам того чи того соціуму неприйнятним [1, с. 292]. Отже, можемо говорити про національноспецифічний характер табу, оскільки не завжди одні й ті самі заборони однаково функціонують у різних суспільствах. Наведемо приклад арабських країн, де полігамність у подружньому житті є цілком законним правом чоловіків, тоді як в Україні офіційно мати кількох дружин нормативно заборонено.

Етнокультурні й національні особливості виражаються й у комунікації певної лінгвоспільноті. М. Стахів наводить кілька рис, які, на ії думку, притаманні українській нації. Найважливіші серед них - доброзичливість, щирість, релігійність, духовну вартість, делікатність і тактовність [8, с. 21]. Неповторна самобутність української нації виявляється також в особливому ставленні до самої мови й слова як такого. У багатьох релігійних обрядах і звичайних побутових комунікативних ситуаціях існує чимало прикладів, які засвідчують причинно-наслідковий зв'язок вживання окремих слів та їхній безпосередній уплив на подальшу долю людини. Зокрема, запитання Куди йдеш? вважається неприйнятним у процесі спілкування, оскільки такі висловлювання можуть спровокувати невдачу для подорожнього. М. Стахів замість наведеного вислову подає більш вдале «Чи далеко зібралися?» Із вірою в магічну силу слова пов'язані й інші вирази-обереги на зразок не при хаті згадуючи, не при печі промовляти, не проти ночі згадуючи, які акцентують увагу на місці й часі ведення розмови, якщо іiі предметом виступає неприпустима в спілкуванні тема, особа або слова, які вживають комуніканти. Табуйованим для обговорення в оселі (за українськими уявленнями, святій місцині), а надто в пізній час є бесіди про померлих, називання представників потойбічних сил (особливо нечистого та його підлеглих), будь-які галасливі брутальні й лайливі вислови тощо.

Про ступінь категоричності й обов'язковості дотримання табу, а також про його культурну детермінованість говорить і Л.Гришаєва. Науковець стверджує: якщо категоричність й обов'язковість будь-якого явища взагалі не обговорюється і воно специфічне й притаманне лише окремій культурі, тоді таке явище можна вважати табу [1, с. 284]. Погодимося 3 таким твердженням ученої, але додамо, що нижчий ступінь категоричності й обов'язковості дотримання певних заборон не виключає належності об'єкта дійсності і, відповідно, його лексем-репрезентанів до системи комунікативних табу, оскільки, як зазначають Я. Попова та Й. Стернін, існують жорсткі та м'які комунікативні табу. Отже, за певних умов порушення різних табу передбачає різне ставлення мовців до комуніканта, який не дотримується таких заборон, - від абсолютного нівелювання процесу комунікації з цією особою та уникання подальших контактів із нею до висловлення відповідного обурення й невдоволення, але збереження можливостей відновлення спілкування за умов дотримання встановлених табу.

○ Ю. В. Єловська, 2013. 
Незважаючи на те, що явище табу за своїм походженням іде вглиб первісних суспільств, не варто обмежувати його існування лише стародавнім світом. У минулому людина керувалася такими заборонами здебільшого через почуття страху перед різноманітними небезпеками, які загрожували iї життю (природні й надприродні сили). І. Гаспаров стверджує, що табу існували протягом усієї історії людства й продовжують виникати у наш час. Головну відмінність між стародавніми й сучасними табу науковець убачає у чіткішій фіксації, як правило, в рамках релігійного законодавства. Оскільки виникнення табу на сучасному етапі пов'язане 3 конфліктами й може загрожувати сталому функціонуванню суспільств, саме релігія, на його думку, здатна захистити соціум від можливих конфліктів і забезпечити його стабільне існування [1, с. 285].

Відповідні зміни відбуваються й у процесі спілкування, де також виявляється динамічний характер комунікативних табу. Раніше бажання уникати в мовленні табуйованих слів спричиняло процеси евфемізації й виникнення нових лексем-репрезентантів табуйованого об'єкта, які через певний проміжок часу самі переходили до розряду заборонених. Нині ж у мовленнєвому дискурсі сучасний i динамічний характер табу зумовлюється зрушеннями в процесах табуїзації й детабуїзації.

Іще кілька десятиліть тому ціла низка тем, що висвітлювала певні соціальні й гендерні аспекти життя нашого суспільства, залишалася під суворою забороною влади (наркоманія, алкоголізм, інтимні стосунки тощо). Значні суспільно-політичні й культурно-історичні зрушення, спричинені розпадом СРСР, сприяли тому, що більшість тем стала вільно обговорюватися в засобах масової інформації, сучасній літературі й у побутовому спілкуванні.

Про тенденцію зв'язку табу з сучасністю та його динамічну природу говорить і М. Тульнова. Погодимось із ученою, що сучасний етап розвитку суспільства, який характеризується процесами глобалізації й трансформації у сфері культури, неминуче вносить зміни до системи цінностей і табу. Завдяки зняттю заборон (детабуїзації) одні комунікативні заборони набувають статусу загальновживаної лексики, і навпаки, у зв'язку з певними змінами, які відбуваються в суспільстві, виникають нові об'єкти, слова, теми, особи, які 3 певних причин підлягають табуюванню (процесу табуїзації) [9, с. 179].

До специфічних ознак комунікативних табу, які функціонують у процесі комунікації, Я. Попова додає умотивованість цього лінгвістичного явища, оскільки воно завжди зумовлене певними чинниками, які його породжують [6]. У первісних суспільствах таким мотиваційним чинником виступав страх. Страх первісної людини перед силами природи (стихії вогню, води, землі, вітру, небесних світил тощо) й надприродними можливостями одноплемінників (чарівників, жерців, чаклунок тощо), вірою в містичні здібності тварин, птахів, речей, у все, що могло спричинити невдачі, нещастя і навіть смерть. Пізніше 3 поступовим 
розширенням знань людини про навколишній світ табу починають розмежовувати на заборони суто релігійного характеру, пов'язані з вірою в потойбічні сили, й морально-етичного характеру, які окреслюють обмеження, що виникають із міркувань етики й моралі. А. Кацев слушно додає, що досить велика кількість табу в мовленні вмотивована відчуттям огиди й відрази до тих об'єктів дійсності, про які заборонено говорити [4]. Характеризуючи тенденції сьогодення, варто зауважити, що табу, які існують у сучасному суспільстві, частково збережені 3 минулих часів, частково тяжіють до етикетних норм, а їхнє дотримання, вмотивоване почуттям обережності, супроводжується використанням в мовленні виразів-оберегів типу тьфр, тьфу, тьфу, иур йому тощо.

Важливою ознакою, на нашу думку, є залежність комунікативних табу від самої комунікативної ситуації й осіб, які вступають в акт комунікації. Часово-просторова складова, яка має висвітлення в наукових розвідках Л. Фроляк і А. Дороги, а також гендерна специфічність, на яку звернули увагу у своїх дослідженнях Т. Джей, Дж.-М. Дьювеле, М. Бахтіяр, накладають певний відбиток на особливості дотримання й порушення комунікативних табу у спілкуванні. Зауважимо, що навіть за умови існування заборон, яких слід дотримуватися всім представникам лінгвоспільноти, допускається порушення «цих неписаних законів», яке зумовлюється, а, отже, й виправдовується певними обставинами комунікативної ситуації. Так, в українському суспільстві обговорення теми особистого життя людини серед колег на робочому місці неприпустиме, а запитання в цьому сенсі сприймаються мовцем принаймні неввічливими. Проте, за умови обговорення делікатних проблем із близькою подругою або родичкою вияви такої цікавості є цілком нормальними.

Услід за Т. Джем, припустимо, що порушення комунікативних табу в спілкуванні зумовлюються прагненням комуніканта надати вислову більшої емоційної забарвленості. Науковець зазначає, що за такої умови заборонені слова (наприклад, лайливі й образливі вислови) можуть вживатися, оскільки в такий спосіб мовець переносить фізичну напруженість i роздратованість на відповідні лексеми i, промовляючи їх, відчуває полегшення. Таке явище здебільшого спостерігається серед чоловіків [13, c. 155]. Вірогідно, цим можна пояснити надмірно жорсткі й образливі коментарі українських інтернет-користувачів під час обговорення дискусійних питань економічного розвитку України, політичних уподобань тощо.

Отже, розвідки, присвячені дослідженню феномена комунікативного табу, неможливі без співвіднесення цього феномена з іншими культурними заборонами, які функціонують у соціумі. Аналіз наукових праць вітчизняних і зарубіжних учених дає можливість виявити соціокультурну детермінованість цих явищ і спільність їхніх ознак (загальнокультурний $\mathrm{i}$ національно-специфічний характер, ступінь категоричності й обов'язковості 
слідування, сучасність і динамічність). Оскільки комунікативні табу охоплюють площину процесу комунікації, яка передбачає наявність своїх специфічних складових, існують також своєрідні особливості комунікативних заборон, спричинені часово-просторовими умовами комунікативної ситуації, умотивованістю та належністю комунікантів до певного кола осіб.

\section{Література}

1. Гришаева Л. И. Культурные табу и их влияние на результат коммуникации / Л. И. Гришаева, Л. В. Цурикова // Вестник ВГУ. Серия : Гум. науки. - Воронеж, 2005. № 2. - С. 282-297.

2. Заніздра Н. О. Напрями сучасного мовознавства / Н. О. Заніздра, В. В. Заніздра // Вісник КДПУ ім. Михайла Остроградського. - Кіровоград, 2008. - Вип. №2 (49). Ч. 1. - С. 21-24.

3. Зеленин Д. К. Табу слов у народов Восточной Европы и Северной Азии / Д. К. Зеленин // Сб. музея антропологи и этнографии. - Л., 1930. - Т. IX. - 164 с.

4. Кацев А. М. Языковые табу и эвфемия : [учеб. пособие к спецкурсу] / А. М. Кацев. - ЛГПИ им. А. И. Герцена. - Л., 1988. - 80 с.

5. Осиянова О. М. Культура речевого общения в аспекте лингвистических исследований / О. М. Осиянова // Вестник ОГУ. - 2009. - № 11(105). - С. 160-165.

6. Попова Я. В. Табу в сфере коммуникативно-языковой актуализации / Я. В. Попова // Язык. Культура. Общество. - 2010. - Вып. 2. - [Електронний pecypc]. - Режим доступу : http://yazik.info/2010-14.php

7. Ригованова В. Языковая личность в аспекте современных лингвистических теорий / В. Ригованова // Наукові записки. Серія : філологічні науки. - Вип. № 89(1). - С. 346-350.

8. Стахів М. Український комунікативний етикет : [навч. посібник] / М. Стахів. К. : Знання, 2008. - 245 с.

9. Тульнова М. А. Табу в контексте глобализации / М. А. Тульнова // Политическая лингвистика. - 2010. - №4(34). - С. 176-181.

10. Формановская Н. И. Речевое общение: коммуникативно-прагматический подход / Н. И. Формановская. - М. : Рус. яз., 2002. - 216 с.

11. Jung Chen $\mathrm{Wu}$ Ph.D. Taboos and English Language Teaching - an Intercultural Perspective. - [Електронний ресурс]. - Режим доступу : http://tw.myblog.yahoo.com

12. Man-ping Chu Chinese culture taboos that affect their language and behaviour choices // Asian Culture and History. 2009. - Vol. 1 No 2 July. - P. 122-139.

13. Timothy Jay The utility and ubiquity of taboo words // Perspectives on psychological science. - Vol. 4 Number 2. - P. 153-160. 